\title{
PENGARUH KAJIAN ZUHUR TERHADAP PEMBENTUKAN AKHLAK KARYAWAN MUSLIM TELKOM DI MASJID AL-ISTIQOMAH TELKOM LANDMARK TOWER
}

\author{
E-ISSN: 2721-7531 \\ Link: https://jurnal-stidnatsir.ac.id/index.php/binaummat/article/view/70 \\ DOI : https://doi.org/10.38214/jurnalbinaummatstidnatsir.v2i02.70 \\ Dikirim: 20-04-2020 \\ Direview: 25-04-2020 \\ Diterbitkan: 17-05-2020 \\ AGUS SAMSONO \\ agussamsono@stidnatsir.ac.id \\ LAILATUL MARDIYAH \\ STID Mohammad Natsir - Indonesia \\ ainulmardiyah1997@gmail.com \\ STID Mohammad Natsir - Indonesia
}

\begin{abstract}
ABSTRAK
Tujuan Penelitian: Penelitian ini bertujuan untuk menganalisis seberapa besar pengaruh kajian Zuhur terhadap pembentukan akhlak karyawan muslim Telkom di Masjid Al-Istiqomah Telkom Landmark Tower. Metode Penelitian: Kuantitatif. Hasil Penelitian: Terdapat pengaruh positif dari kajian Zuhur dalam pembentuk akhlak karyawan muslim Telkom di Masjid Al-Istiqomah Telkom Landmark Tower, pengaruh tersebut dapat diketahui dari perhitungan yang didapat melalui SPSS dapat diketahui bahwa nilai koefisien atau rxy adalah sebesar 0,285 . Hal ini juga dibuktikan dengan menggunakan koefisien determinasi yang hasilnya $8,1 \%$. Hal tersebut menunjukkan bahwa 8,1\% akhlak karyawan muslim Telkom di Masjid Al- Istiqomah Telkom Landmark Tower dipengaruhi oleh kajian Zuhur dan sisanya dipengaruhi oleh variabel yang lain.
\end{abstract}

Kata kunci: pengaruh, kajian zuhur, akhlak, karyawan muslim, Telkom 


\section{PENDAHULUAN}

Salah satu misi dakwah Rasulullah Shallallahu 'Alaihi wa Sallam adalah menyempurnakan akhlak manusia. Sebagaimana sabda beliau: "Sesungguhnya aku diutuskan untuk menyempurnakan akhlak mulia." (AlBukhari dalam al-Adab al-Mufrad (no. 273). Perlu dipahami bahwa hadits di tersbut tidak berbicara mengenai proses dakwah tapi tujuan diutusnya Nabi Muhammad Shallallahu 'Alaihi wa Sallam.

Untuk mendidik umatnya dan membangun peradaban, Rasulullah saw, menggunakan masjid sebagai pusatnya, dan bangunan yang pertama kali dibangun oleh Rasulullah Shallallahu 'Alaihi wa Sallam sesampainya di Madinah ialah Masjid Quba'. Miftah Farid mengatakan bahwa masjid juga mempunyai peran dan fungsi yang sangat penting dalam Islam dalam upaya membentuk pribadi dan kepribadian masyarakat yang Islami. Masjid pada zaman Rasulullah Shallallahu 'Alaihi wa Sallam memiliki beberapa fungsi diantaranya: sebagai tempat pendidikan, santunan sosial, latihan militer dan persiapan alat-alatnya, tempat pengobatan para korban perang, tempat mendamaikan dan menyelesaikan sengketa, tempat menerima utusan delegasi atau tamu, sebagai pusat penerangan dan pembelaan agama.

Masjid pada zaman modern di Indonesia dikelola oleh Dewan Kemakmuran Masjid (DKM) untuk memakmurkan masjid dengan berbagai kegiatan. Diantara bentuk kegiatan masjid adalah pengajian. Pengajian merupakan salah satu bentuk kegiatan dakwah. Pengajian tidak hanya dilakukan umat Islam di masjid-masjid sekitar tempat tinggal, namun di tempat kerja seperti perusahaan milik swasta, maupun milik negara seperti BUMN, Diantara BUMN yang memberikan perhatian serius terhadap pembinaan akhlak (karakter) karyawan adalah Telkom. Dengan adanya karakter karyawan yang kuat diyakini memiliki korelasi dengan perbaikan dan peningkatan kinerja perusahaan. Teuku Muda Nanta selaku Executive Vice President Telkom Regional II Jakarta mengatakan, "Salah satu kekuatan Telkom Indonesia berada pada sumber daya manusianya. Sumber daya manusia tidak hanya kita tingkatkan kompetensinya saja, tetapi juga spiritual karakter. Di Telkom terdapat program pembinaan spiritual dan program tersebut telah berlangsung sejak tahun 2013 sampai sekarang."

Berdasarkan hal-hal tersebut, maka seluruh insan muslim Telkom Group bermufakat untuk membentuk wadah silaturahim antar seluruh insan muslim Telkom Group dalam suatu organisasi yang bersifat terbuka dan dalam rangka mensyiarkan nilai-nilai Islam di lingkungan Telkom 
Group serta sebagai wadah pembinaan spiritual bagi karyawan. Majelis Taklim yang dimiliki oleh Telkom diberinama Majelis Taklim Telkom Group (MTTG). Majlis Taklim Telkom Group (MTTG) inilah yang menghandel kegiatan keagamaan, khususnya agama Islam di perusahaan Telkom. Ada beberapa bidang yang dimiliki oleh MTTG dalam rangka pembinaan karyawan Telkom antara lain; Bidang dakwah, bidang ekonomi dan pendanaan, bidang olahraga dan seni, bidang digital multimedia, bidang ZIS dan sosial, bidang perlengkapan dan bidang keputrian. Dari ke tujuh bidang yang ada di MTTG, ada satu bidang yang khusus menangani kegiatan dakwah yaitu bidang dakwah dan kemakmuran masjid (DKM).

Bidang dakwah dan kemakmuran masjid ini memiliki beberapa tugas diantaranya; memastikan terselenggaranya ibadah sholat berjamaah di Masjid Al-Istiqomah Telkom Landmark Tower dengan baik dan lancar (kecuali untuk sholat subuh yang disesuaikan dengan event), mengkoordinir pelaksanaan dan penyusunan jadwal kegiatan rutin (taklim pagi, kajian zuhur, pembacaan hadits setelah sholat ashar, khutbah jumat, kajian muslimah, kajian pengurus, tahsin, tahfidz dan lain-lain), dan menyemarakkan hari-hari besar Islam, khususnya memperbanyak program-program taklim dan sosial di bulan Ramadhan.

Dalam menjalankan fungsinya sebagai sarana dakwah, Masjid AlIstiqomah Telkom Landmark Tower yang berada di bawah kepengurusan MTTG menyelenggarakan beberapa kegiatan rutin salah satunya yaitu kajian Zuhur. Kajian Zuhur ini telah dilaksanakan sejak tahun 1995 serta rutin diadakan setiap hari Senin hingga Kamis dari pukul 12.00-13.00 WIB. Jama'ah yang mengikuti kajian ini yaitu para karyawan Telkom Group yang berada di gedung Graha Merah Putih dan Telkom Landmark Tower.

Kajian Zuhur ini merupakan salah satu sarana yang digunakan untuk melakukan pembinaan akhlak karyawan muslim. Pembinaan akhlak ini bertujuan untuk memantapkan implementasi spiritual kerja para karyawan Telkom. Materi yang disampaikan dalam kajian inipun telah disusun secara tematik bersilabus dengan harapan materi yang disampaikan dapat melahirkan akhlak yang baik dalam diri para karyawan. Dengan akhlak yang baik tersebut dapat menjadikan karyawan Telkom menjadi insan yang yang tidak hanya sukses dalam urusan dunia namun sukses juga dalam urusan akhirat. Kajian Zuhur di Masjid Al-Istiqomah Telkom Landmark Tower merupakan bagian dari kegiatan dakwah MTTG, dan salah satu tujuan dakwah adalah menyempurnakan akhlak. 
Di dalam kajian Zuhur sendiri terdapat para da'i yang siap menyampaikan ilmunya kepada para karyawan. Selain itu materi kajian dan media atau sarana juga telah tersedia untuk para karyawan yang ingin mengikuti kajian Zuhur tersebut. Para pengurus yang mengkoordinir kajian Zuhur telah mempersiapkan berbagai sarana yang menunjang terlaksananya kajian Zuhur. Dari kegiatan kajian Zuhur yang dilaksanakan di Masjid Al-Istiqomah apabila para jamaah mengimplementasikan apa yang disampaikan oleh para penceramah terutama materi akhlak, maka akan menjadi pribadi yang berakhlak mulia dan sebaliknya apabila ilmu yang mereka dapat tidak diamalkan atau bahkan di abaikan maka akan menjadikan pribadi dengan akhlak tercela.

Kajian Zuhur di Masjid Al-Istiqomah Telkom Landmark Tower merupakan bagian dari kegiatan dakwah MT'TG yang sudah berlangsung selama 22 tahun (2019), dan salah satu tujuan dakwah adalah menyempurnakan dan merubah akhlak. Penelti tertarik untuk meneliti apakah seberapa besar pengaruh dari kajian Zuhur terhadap pembentukan akhlak karyawan.

\section{HASIL DAN DISKUSI}

\section{Da'wah dan Perubahan Akhlak}

Dakwah berasal dari bahasa Arab yang diambil dari kata ( يَذَعْوْ دَ) yang artinya menyeru, mengajak, memanggil, menjamu, kemudian menjadi kata دَعَوَ yang artinya seruan, panggilan, ajakan, jamuan. ${ }^{1}$ Jadi kata dakwah merupakan isim mashdar yang berasal dari fi'il madhi دَّ yang artinya panggilan, seruan, atau ajakan. ${ }^{2}$ Dari sini dapat kita ketahui bahwa dakwah adalah satu kegiatan mengajak, memanggil, menyeru orang lain kepada apa yang diinginkan syariat Islam secara terencana, terukur dan terevaluasi.

Definisi dakwah secara istilah yaitu, segala usaha dan kegiatan yang disengaja dan terencana dalam wujud sikap, ucapan dan perbuatan yang mengandung ajakan dan seruan baik langsung maupun tidak langsung

1 Mahmud Yunus, Kamus Bahasa Arab-Indonesia, Jakarta:Yayasan Penyelenggara/Penafsiran Al-Qur'an, 1973, hal.127

${ }^{2}$ Hasanudin, Hukum Dakwah Tinjauan Aspek Hukum dalam Berdakwah di Indonesia, Jakarta: Pedoman Ilmu Jaya, 1996, hal. 26 
ditujukan kepada perorangan, masyarakat atau golongan supaya tergugah jiwanya, terpanggil hatinya kepada ajaran Islam untuk selanjutnya mempelajari dan menghayati serta mengamalkannya dalam kehidupan sehari-hari. Fawwaz bin Hulayyil as-Suhaimi dalam bukunya yang berjudul Begini Seharusnya Berdakwah menyatakan bahwa, "Dakwah adalah mengajak orang lain agar melakukan segala perintah Allah Subbaanabu wa Ta'ala, baik berupa ucapan atau amalan dan meninggalkan segala larangan Allah, baik berupa ucapan atau perbuatan." 3

Hukum berdakwah adalah wajib atas setiap individu muslim, sehingga salah apabila ada yang mengira bahwa dakwah hanya diwajibkan kepada ulama dan para ustadz saja, sedangkan di luar golongan tersebut tidak ada kewajiban untuk berdakwah. ${ }^{4}$ Dengan demikian, dapat kita simpulkan bahwa tugas dakwah ini bukan hanya dijalani oleh ulama saja.

\section{Unsur-Unsur Dakwah}

Unsur-unsur dakwah adalah komponen-komponen yang terdapat dalam setiap kegiatan dakwah. Unsur-unsur tersebut adalah:

a). Da'i. Dai adalah yaitu orang yang melakukan kegiatan dakwah atau orang yang menyampaikan ajaran Islam, yang mengajarkannya dan yang giat untuk mengamalkannya. ${ }^{5}$ Seorang da'i hendaknya memiliki beberapa kemampuan dalam berretorika. Diantara retorika dalam bahasa percakapan adalah mengucapkan kata-kata yang tepat, benar dan mengesankan di tempat yang tepat, waktu yang tepat, dan cara yang efektif. $\mathrm{Hal}$ itu berarti orang tersebut harus dapat berbicara jelas, singkat dan efektif. Jelas agar mudah dimengerti, singkat untuk menghemat waktu dan sebagai tanda kepintaran dan efektif karena berbicara dengan membawa efek. ${ }^{6}$ Da'i harus memperhatikan seorang da'i saat berceramah (pidato) ${ }^{7}$ :

3 Fawwaz bin Hulayyil as-Suhaimi, Begini Seharusnya Berdakwah. Jakarta:Darul Haq, 2015, hal.19

${ }^{4}$ A. Syamsuri Shidiq, Da'wah dan Teknik Berkhutbah, Bandung: Pustaka AlMa'arif, 1981, hal 12

${ }^{5}$ Hamdan bin Nashir bin Abdurrahman al-Ammar, Asalib al-Da'wah alMu'ashirah, hal. 40

${ }^{6}$ Yusuf Zainal Abidin, Pengantar Retorika, Bandung: Pustaka Setia, 2013, hal. 56

${ }^{7}$ Ibid, 177

95 | Jurnal Bina Ummat | Vol.3 | No.1 | 2020 
posisi berbicara, mengatur suara dalam berceramah. volume, intonasi, dan pelafalan, gerak tubuh dan mikrofon.

Mad'u, mad'u dapat dikatakan pula mitra dakwah atau penerima dakwah. Mad'u yaitu manusia yang menjadi sasaran dakwah atau manusia penerima dakwah, baik sebagai individu maupun sebagai kelompok, baik manusia yang beragama Islam maupun tidak, atau dengan kata lain manusia secara keseluruhan. ${ }^{8}$

Maddah (Materi Dakwah), maddah dakwah adalah isi pesan atau materi yang disampaikan da'i kepada mad'u. Dalam hal ini sudah jelas bahwa yang menjadi materi adalah apa yang diwahyukan oleh Allah Ta'ala kepada Rasul-Nya yang terdapat dalam Al-Qur'an dan As-Sunnah. ${ }^{9}$ d).

Metode, Metode dakwah atau kaifiyyatudda'wah adalah jalan atau cara yang dipakai juru dakwah (da'i) untuk menyampaikan materi dakwah. Sebagaimana firman Allah Subhanahu wa Ta'ala dalam Q.S. An-Nahl: 125. Ayat ini menyebutkan bahwa ada beberapa metode dakwah yaitu : Metode Hikmah Metode Manizah Hasanah Metode Mujadalah ${ }^{10}$

Washilah (Media Dakwah), media berasal dari bahasa Latin medius yang secara harfiah berarti perantara, tengah atau pengantar. Dalam bahasa Inggris media merupakan bentuk jamak dari medium yang berarti tengah, antara, rata-rata. Dari pengertian ini ahli komunikasi mengartikan media sebagai alat yang menghubungkan pesan komunikasi yang disampaikan oleh komunikator kepada komunikan (penerima pesan).

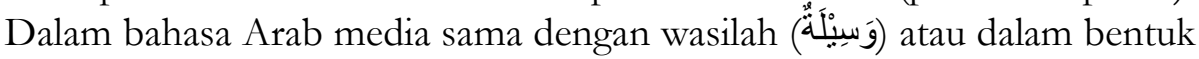

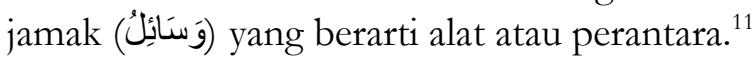

\section{Pengertian Akhlak}

${ }^{8}$ Moh. Ali Aziz, Ilmu Dakwah, Jakarta: Prenada Media, 2004, Cet. I, hal. 79

${ }^{9}$ Abdul Karim Zaidan, Ushulud Da'wah, Beirut: Al-Resalah, 2005, hal. 7

${ }^{10}$ Fawaz bin Hulail bin as-Suhaimi, Pokok-pokok Dakwah Manhaj Salaf, hal. 195

${ }^{11}$ Moh. Ali Aziz, Ilmu Dakwah, Jakarta: Prenada Media Group, 2009, hal. 403 
Kata akhlak menurut kamus "al-munawir" berasal dari kata: Khalaqa-yakbluqu-khuluqun jama'nya akblaaqun, artinya tabiat, budi pekerti. ${ }^{12}$ Hamzah Yaqub berpendapat bahwa, "perkataan akhlak berasal dari bahasa arab, jama” dari خلق yang menurut lughat (bahasa) diartikan budi pekerti, perangai, tingkah laku." ${ }^{\prime \prime 3}$

Kata akhlak merupakan bentuk jama' (plural) dari kata tunggal kbuluq. Kata khuluq dalam kamus shahih berarti tabiat atau perangai. Imam Al-Qurthubi dalam tafsirnya menjelaskan, "Khuluq dalam bahasa arab artinya adalah adab atau etika yang mengendalikan seseorang dalam bertindak atau bersikap." 14

\section{Macam-Macam Akhlak}

Orang yang berakhlak adalah orang yang dapat membedakan antara yang baik dan yang buruk. Adapun kriteria-kriteria akhlak baik dan buruk adalah sebagai berikut: Akhlak Mulia (al-Karimab). Akhlak mulia adalah segala perbuatan (tingkah laku) yang baik sesuai dengan ajaran Islam, seperti apa yang dicontohkan Nabi Muhammad Shallallahu 'alaibi wa sallam. Untuk menjadi seorang muslim yang berakhlak mulia, tentu kita perlu memahami benar maksud dari akhlak mulia itu sendiri menurut syari'at Islam.

Adapun kriteria akhlak mulia dilihat dari segi hubungan manusia dengan Allah Subhanahu wa Ta'ala, terhadap sesama manusia dan diri sendiri antara lain:

\section{Akhlak terhadap Allah}

Yang dimaksud dengan berakhlak mulia terhadap Allah Subhanahu wa Ta'ala adalah berserah diri hanya kepada-Nya, bersabar, ridha terhadap hukumnya baik dalam masalah syari'at maupun takdir, dan tidak berkeluh kesah terhadap hukum syari'at dan takdir-Nya. ${ }^{15}$ Adapun berakhlak mulia

12 Ahmad Warsono Munawwir, Kamus Munawwir, Surabaya: Pustaka Progressif, 1996, hal. 364

${ }^{13}$ Hamzah Yaqub, Etika Islam, Bandung: Diponegoro, 1983, hal. 11

${ }^{14}$ Abu Ammar, dan Abu Fatiah Al-Adnani, Mizanul Muslim, Solo: Cordova Media, 2009, hal. 400

15 Ummu Annas Sumayyah bintu Muhammad Al-Anshariyyah, Meraih Kemuliaan Akhlak, Jakarta: Griya Ilmu, 2018, hal. 17 
terhadap Allah Subhanabu wa Ta'ala diantaranya adalah sebagai berikut: (a) Muraqabah (Muraqabah adalah keyakinan seseorang hamba bahwa Allah Maha Mengawasi gerak-geriknya dan Maha Mengerahui segala sesuatu tentang dia baik lahir maupun batin). ${ }^{16}$ (b) Takut kepada Allah (c) Ikhlas (d) Syukur

\section{Akhlak terhadap sesama manusia}

Yang dimaksud berakhlak mulia terhadap sesama manusia adalah tidak menyakiti mereka dengan lisan dan anggota badan, mengucap salam ketika bertemu, menahan amarah, sabar terhadap gangguan mereka, rendah hati, jujur, amanah dan lain-lain. Berikut ini adalah beberapa akhlak mulia terhadap sesama manusia: (a) Kasih sayang (b) amanah (c) Menjaga lisan

\section{Akhlak terhadap Diri Sendiri}

Diantara akhlak terhadap diri sendiri adalah (a) Muhasabah, muhasabah adalah sebuah upaya evaluasi diri terhadap kebaikan dan keburukan dalam semua aspek. Muhasabah merupakan salah satu sarana yang dapat mengantarkan manusia mencapai tingkat kesempurnaan sebagai hamba Allah Ta'ala. ${ }^{17}$ (2) Taubat, yang dimaksud taubat adalah menyucikan diri dari berbagai dosa dan maksiat, menyesali segala dosa yang telah dilakukan dan bertekad untuk tidak kembali kepada dosa tersebut di masa yang akan datang.

\section{Akhlak Tercela}

Diantara akhlak tercela adalah (a) sombong, yaitu merasa lebih tinggi dari orang lain atau seseorang yang yakin bahwa dirinya lebih mulia dari manusia atau dia memiliki kelebihan dari pada mereka. ${ }^{18}$ (b) Marah, marah adalah kondisi yang kadang menimpa manusia, bahkan terkadang manusia tidak dapat menghindarinya. Marah adalah perubahan pada diri atau emosi yang dibawa oleh kekuatan dan rasa dendam demi

${ }^{16}$ Ummu Ihsan dan Abu Ihsan al-Atsari, Aktualisasi Akhlak Muslim, hal. 149

${ }^{17}$ Kutipan pernyataan Ahmad Kusyairi Suhail (Sekjen Ikatan Da'i Indonesia, IKADI) Pentingnya muhasabah, Republika.co.id Kamis, 4 April 2019

18 Ummu Anas Sumayyah bintu Muhammad Al-Anshariyyah, Meraih Kemuliaan Akhlaq,hal. 88 
menghilangkan gemuruh di dada. Rasulullah Shallallahu 'alaibi wa Sallam telah mewasiatkan kepada seorang laki-laki:

\section{"Jangan marah?"}

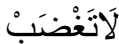

Ibnu Hajar rabimabullab berkata dalam al-Fath: "Al-Khaththabi berkata" "Arti perkataan beliau jangan marah, adalah jauhi sebab-sebab marah dan jangan melakukan sesuatu yang mengarah kepadanya. Sementara marah itu sendiri tidaklah terlarang karena ia adalah tabiat yang tidak akan hilang dari diri manusia." Akan tetapi hendaknya seorang muslim memperhatikan adab-adab yang berkaitan dengan marah. ${ }^{19}$

\section{Operasional Variabel dan Variabel Penelitian}

\section{Operasional Variabel}

a. Variabel X (Kajian Zuhur)

1) Penceramah: Penceramah di sini yaitu para narasumber yang mengisi kajian Zuhur di masjid Al-Istiqomah Telkom Landmark Tower.

2) Materi: Materi yang disampaikan kepada para karyawan Muslim Telkom yaitu berkisar antara syari'ah, aqidah dan akhlak. Dalam penelitian ini, penulis menfokuskan penelitiannya pada materi akhlak yang disampaikan pada saat kajian Zuhur.

3) Metode: Yang dimaksud metode di sini adalah cara menyampaikan dakwah pada kajian Zuhur yang digunakan masjid Al-Istiqomah Telkom Landmark Tower dalam berdakwah kepada para karyawan.

4) Media: Sarana yang digunakan oleh masjid Al-Istiqomah Telkom Landmark Tower dalam kajian Zuhur yaitu ceramah. Alat-alat yang mendukung kajian Zuhur antara lain: monitor, microphone, soundsystem dan camera yang berfungsi untuk merekam ceramah dalam kajian Zuhur.

b. Variabel Y (Akhlak)

Akhlak mulia inilah yang membentuk akhlak karyawan Muslim di Telkom. Akhlak dibagi menjadi dua, yaitu akhlak mulia dan akhlak yang tercela. Akhlak mulia terbagi menjadi tiga yaitu:

${ }^{19}$ Abdul Aziz bin Fathi as-Sayyid Nada, Ensiklopedi Adab Islami, Jakarta: Pustaka Imam Syafi'i, 2013, hal. 302 
1) Akhlak kepada Allah

a) Muraqabah: adalah keyakinan seseorang hamba bahwa Allah Maha Mengawasi gerak-geriknya dan Maha Mengetahui segala sesuatu tentang dia baik lahir maupun batin.

b) Takut kepada Allah: Rasa takut kepada Allah ini mampu membuat seorang mukmin menjadikan segala ibadahnya ikhlas karena Allah semata, karena dia khawatir akan terjebak ke dalam perangkap riya dan sifat munaik

c) Ikhlas: Akhlak mulia pertama dan utama yang wajib dimiliki seorang mukmin adalah ikhlas. Yaitu mengerjakan sesuatu demi mengharap keridhaan Allah Subhanahu wa Ta'ala semata.

d) Syukur: Syukur adalah menunjukkan adanya nikmat Allah pada dirinya. Dengan melalui lisan, yaitu berupa pujian dan mengucapkan kesadaran diri bahwa ia telah diberi nikmat. Dengan melalui hati, berupa persaksian dan kecintaan kepada Allat Ta'ala. Melalui anggota badan, berupa kepatuhan dan ketaatan kepada Allah.

2) Akhlak kepada Sesama Manusia

a) Kasih Sayang: Sifat penyayang merupakan tanda kelapangan dada, kelembutan hati, dan keluhuran budi pekerti. Seseorang yang berakhlak mulia akan dimudahkan untuk mengetahui kebenaran. Ia menyayangi seluruh manusia serta seluruh makhluk, maka ia disayangi oleh manusia dan seluruh makhluk. Rasa kasih sayang ini sangat dibutuhkan bagi para karyawan, agar kompak dan solid dalam menjalankan pekerjaan.

b) Amanah: Amanah adalah sesuatu yang harus dijaga dan dipelihara agar sampai kepada pemiliknya. Dalam hal ini maksudnya yaitu kewajiban yang harus dilaksanakan oleh para karyawan dalam pekerjaannya.

c) Menjaga Lisan: Bertutur kata yang baik adalah tanda beriman kepada Allah dan hari akhir. Dan perilaku yang harus diperhatikan dalam sebuah organisasi atau perusahaan.

3) Akhlak Kepada Diri Sendiri

a) Muhasabah: Muhasabah adalah sebuah upaya evaluasi diri terhadap kebaikan dan keburukan dalam semua aspek. Muhasabah merupakan salah satu sarana yang dapat 
mengantarkan manusia mencapai tingkat kesempurnaan sebagai hamba Allah Ta'ala.

b) Taubat: Taubat ialah menyucikan diri dari berbagai dosa dan maksiat, menyesali segala dosa yang telah dilakukan dan bertekad tidak kembali kepada dosa tersebut dimasa yang akan datang. Taubat inilah yang membuat para karyawan menjadi manusia yang lebih baik.

Sedangkan akhlak tercela adalah akhlak yang akan melahirkan tabiat yang tidak terpuji. Diantara akhlak tercela yaitu:

1) Sombong: Sombong adalah merasa lebih tinggi dari orang lain atau seseorang yang yakin bahwa dirinya lebih mulia dari manusia atau dia memiliki kelebihan dari pada mereka.

2) Marah: Marah adalah perubahan pada diri atau emosi yang dibawa oleh kekuatan dan rasa dendam demi menghilangkan gemuruh di dada.

\section{Variabel Penelitian}

Penelitian ini memiliki dua variabel, yaitu variabel bebas (independent variable) dan variabel terikat (dependent variable). Variabel bebas merupakan variabel yang mempengaruhi variabel lain atau menghasilkan akibat pada variabel yang lain, yang pada umumnya berada dalam urutan tata waktu yang terjadi lebih dulu. Sedangkan variabel terikat merupakan variabel yang tergantung atas variabel yang lain. ${ }^{20}$

Pada penelitian ini variabel pertama adalah kajian Zuhur sebagai variabel bebas (variabel $\mathrm{X}$ ), dan variabel yang kedua adalah akhlak karyawan Telkom Landmark Tower sebagai variabel terikat (variabel Y).

\section{Tabel 1}

Variabel Penelitian

\begin{tabular}{|l|l|l|}
\hline Variabel X & Dimensi Variabel & Indikator Variabel \\
\hline & \multirow{4}{*}{ 1. Da'i } & $\begin{array}{c}\text { a. Penceramah menyampaikan } \\
\text { kajian dengan bahasa yang } \\
\text { santun dan mudah dipahami }\end{array}$ \\
& $\begin{array}{c}\text { b. Intonasi bicara penceramah } \\
\text { mudah untuk didengar }\end{array}$ \\
\hline
\end{tabular}

${ }^{20}$ Mohammad Nazir, Metode Penelitian, Bogor: Ghalia Indonesia, 2014, hal. 108

101 | Jurnal Bina Ummat | Vol.3 | No.1 | 2020 


\begin{tabular}{|c|c|c|}
\hline \multirow{7}{*}{$\begin{array}{l}\text { Kajian } \\
\text { Zuhur }\end{array}$} & & $\begin{array}{l}\text { c. Gaya bicara penceramah saat } \\
\text { berceramah tidak } \\
\text { menjemukan }\end{array}$ \\
\hline & \multirow[t]{2}{*}{ 2. Materi } & $\begin{array}{l}\text { a. Materi yang disampaikan } \\
\text { oleh penceramah sesuai } \\
\text { dengan kebutuhan karyawan }\end{array}$ \\
\hline & & $\begin{array}{l}\text { b. Tema kajian yang } \\
\text { disampaikan bervariasi }\end{array}$ \\
\hline & \multirow[t]{3}{*}{ 3. Metode } & $\begin{array}{l}\text { a. Penceramah menggunakan } \\
\text { metode kisah dalam } \\
\text { penyampaian kajian }\end{array}$ \\
\hline & & $\begin{array}{l}\text { b. Penceramah membuka sesi } \\
\text { tanya jawab saat kajian }\end{array}$ \\
\hline & & $\begin{array}{l}\text { c. Penceramah menggunakan } \\
\text { nasihat yang membekas di } \\
\text { hati }\end{array}$ \\
\hline & 4. Media & $\begin{array}{l}\text { a. Panitia membuat pamplet } \\
\text { online (flayer) yang } \\
\text { dipublikasikan ke jamaah } \\
\text { sebelum kajian dimulai }\end{array}$ \\
\hline \multirow[t]{8}{*}{ Variabel X } & Dimensi Variabel & Indikator Variabel \\
\hline & $\begin{array}{l}\text { A. Akhlak kepada Allah } \\
\text { 1. Muraqabah }\end{array}$ & $\begin{array}{l}\text { a. Melaksanakan sholat } \\
\text { fardhu diawal waktu } \\
\text { secara berjamaah }\end{array}$ \\
\hline & & $\begin{array}{l}\text { b. Apabila ada kotak } \\
\text { infaq, menyisihkan } \\
\text { sebagian uang untuk } \\
\text { diinfaqkan }\end{array}$ \\
\hline & & $\begin{array}{l}\text { c. Membaca basmalah } \\
\text { (doa) ketika akan } \\
\text { memulai pekerjaan }\end{array}$ \\
\hline & & $\begin{array}{l}\text { d. Meminta petunjuk } \\
\text { Allah Subbaanabu wa } \\
\text { Ta'ala dalam setiap } \\
\text { mengambil keputusan }\end{array}$ \\
\hline & 2. Takut kepada Allah & $\begin{array}{l}\text { a. Merasa gelisah dan } \\
\text { menyesal ketika } \\
\text { melakukan kesalahan }\end{array}$ \\
\hline & 3. Ikhlas & $\begin{array}{l}\text { a. Bersemangat dalam } \\
\text { bekerja untuk } \\
\text { mendapat ridho Allah } \\
\text { Ta'ala }\end{array}$ \\
\hline & 4. Syukur & $\begin{array}{l}\text { a. } \\
\text { Bersyukur dan } \\
\text { (alhamdulillah) ketika } \\
\text { mendapat nikmat. }\end{array}$ \\
\hline
\end{tabular}




\begin{tabular}{|c|c|c|c|}
\hline \multirow{13}{*}{ Akhlak } & & & $\begin{array}{l}\text { Apabila mendapat } \\
\text { ujian, bersabar dan } \\
\text { yakin bahwa ujian } \\
\text { tersebut baik. }\end{array}$ \\
\hline & \multirow[t]{4}{*}{$\begin{array}{l}\text { B. Akhlak kepada Manusia } \\
\text { 1. Kasih sayang }\end{array}$} & a. & $\begin{array}{l}\text { Mengucapkan salam } \\
\text { ketika bertemu dengan } \\
\text { rekan kerja }\end{array}$ \\
\hline & & b. & $\begin{array}{l}\text { Mendoakan dan } \\
\text { menjenguk saudara } \\
\text { yang sedang sakit }\end{array}$ \\
\hline & & c. & $\begin{array}{l}\text { Membantu rekan kerja } \\
\text { yang sedang mengalami } \\
\text { kesulitan }\end{array}$ \\
\hline & & d. & $\begin{array}{l}\text { Senang jika rekan kerja } \\
\text { berprestasi dan } \\
\text { mendapat penghargaan } \\
\text { dari pimpinan }\end{array}$ \\
\hline & \multirow[t]{3}{*}{ 2. Amanah } & a. & $\begin{array}{l}\text { Menjalankan apa yang } \\
\text { diperintah pimpinan } \\
\text { dengan senang hati }\end{array}$ \\
\hline & & b. & $\begin{array}{l}\text { Datang ke kantor tepat } \\
\text { waktu }\end{array}$ \\
\hline & & c. & $\begin{array}{l}\text { Menyelesaikan tugas } \\
\text { kantor tepat waktu }\end{array}$ \\
\hline & 3. Menjaga Lisan & a. & $\begin{array}{l}\text { Menjaga lisan dari } \\
\text { pembicaraan yang tidak } \\
\text { bermanfaat seperti } \\
\text { halnya membicarakan } \\
\text { aib rekan kerja (gosip) }\end{array}$ \\
\hline & $\begin{array}{l}\text { C. Akhlak terhadap Diri } \\
\text { Sendiri } \\
\text { 1. Muhasabah } \\
\end{array}$ & a. & $\begin{array}{l}\text { Introspeksi diri atas } \\
\text { kesalahan yang telah di } \\
\text { lakukan }\end{array}$ \\
\hline & 2. Taubat & b. & $\begin{array}{l}\text { Ketika melakukan } \\
\text { kesalahan, mengucap } \\
\text { istighfar }\end{array}$ \\
\hline & $\begin{array}{l}\text { D. Akhlak Tercela } \\
\text { 1. Sombong }\end{array}$ & a. & $\begin{array}{l}\text { Tidak berbangga diri } \\
\text { (sombong) apabila } \\
\text { mendapat nikmat }\end{array}$ \\
\hline & 2. Marah & b. & $\begin{array}{l}\text { Apabila ada masalah, } \\
\text { menyelesaikan dengan } \\
\text { baik-baik tanpa emosi }\end{array}$ \\
\hline
\end{tabular}

Populasi dan sampel obyek penelitian ini ialah para karyawan yang mengikuti kajian Zuhur di masjid Al-Istiqomah Telkom Landmark Tower. Dengan mengambil sampel yang cukup mewakili dari populasi yang diteliti. Populasi karyawan yang mengikuti kajian Zuhur ini berjumlah 100 orang. 
Dalam pengambilan jumlah sampel peneliti menggunakan rumus Slovin, yaitu sebagai berikut:

$$
\begin{aligned}
& \qquad n=\frac{N}{1+N e^{2}} \\
& \mathrm{n}=\text { Jumlah sampel } \\
& \mathrm{N}=\text { Jumlah populasi } \\
& \mathrm{e}=\text { Batas kesalahan maksimal yang ditolerir dalam sampel }(5 \%)
\end{aligned}
$$

Berdasarkan rumus Slovin di atas, jika populasi berjumlah 100 orang dengan batas kesalahan maksimal yang ditolerir dalam sampel $5 \%$. Maka sampel yang dibutuhkan adalah 80 orang karyawan Telkom yang mengikuti kajian Zuhur di Masjid Al-Istiqomah Telkom Landmark Tower. Teknik pengumpulan data dalam penelitian ini adalah observasi, wawancara, dan kuesioner. Dalam penelitian ini penulis menggunakan participant observation (observasi berperan serta), dimana penulis ikut bergabung dan mengamati kegiatan kajian Zuhur yang diikuti oleh para karyawan Telkom di Masjid Al-Istiqomah Telkom Landmark Tower. Dalam hal ini penulis melakukan wawancara dengan Mantan ketua DKM Masjid Al-Istiqomah, ketua Majelis Ta'lim Telkom Group Pusat, Karyawan Telkom, serta narasumber kajian Zuhur. Dalam hal ini penulis menggunakan kuesioner tertutup, yaitu pertanyaan-pertanyaan yang diberikan kepada responden sudah dalam pilihan ganda, sehingga responden tidak diberi kesempatan untuk mengeluarkan pendapat.

Pengukuran dalam penelitian ini menggunakan skala Likert. ${ }^{21}$ Skala Likert ini berisi pernyataan yang sistematis untuk menunjukkan sikap seorang responden terhadap pernyataan itu. ${ }^{22}$ Dengan frekuensi sebagai berikut: Selalu diberi skor 4, Sering diberi skor 3 Kadang-kadang diberi skor 2 Tidak Pernah diberi skor 1. Analisis data yang digunakan adalah analisis data kuantitatif dengan statistic deskriptif presentasi untuk melihat hasil dari jawaban responden dan statistik Inferensial denga korelasi product untuk menentukan hubungan antara dua gejala interval dengan menggunakan bantuan program SPSS (Statistical Package for Social

${ }^{21}$ Sugiyono, Metode Penelitian Kuantitatif Kualitatif dan $R \& D$, Bandung: Alfabeta, 2011, hal. 93

${ }^{22}$ Proyono, Metode Kuantitatif, Sidoarjo: Zifatama Publishing, 2008, hal. 107 
Sciences. ${ }^{23}$ Indeks korelasi " $\mathrm{r}$ " product moment maka dilakukan interpretasi secara sederhana yaitu dengan mencocokkan hasil penelitian dengan angka indeks korelasi " $\mathrm{r}$ " product moment ${ }^{24}$.

Untuk lebih memudahkan pemberian interpretasi angka indeks korelasi " $r$ " Product Moment, prosedurnya adalah:

Merumuskan hipotesa alternatif (Ha) dan hipotesa nihil (Ho)

$H a$ : Terdapat pengaruh antara kajian Zuhur terhadap pembentukan akhlak karyawan di masjid Al-Istiqomah Telkom Landmark Tower.

Ho: Tidak terdapat pengaruh antara kajian Zuhur terhadap pembentukan akhlak karyawan di masjid Al-Istiqomah Telkom Landmark Tower.

Untuk mencari kontribusi variabel $\mathrm{X}$ terhadap variabel $\mathrm{Y}$, penulis menggunakan rumus sebagai berikut:

$$
\mathrm{KD}=\mathrm{r}^{2} \times 100 \%
$$

Keterangan:

$\mathrm{KD}=$ kontribusi variabel $\mathrm{X}$ terhadap variabel $\mathrm{Y}$ (koefisien determinan)

$\mathrm{r}^{2} \quad=$ koefisien korelasi variabel $\mathrm{X}$ terhadap variabel $\mathrm{Y}^{25}$

\section{HASIL DAN DISKUSI}

\section{Analisis Statistik Deskriptif}

Data-data yang diperoleh dalam meneliti pengaruh kajian Zuhur terhadap pembentukan akhlak karyawan Telkom di Masjid Al-Istiqomah Telkom Landmark Tower diperoleh melalui observasi, wawancara, dan angket. Wawancara penulis lakukan dengan Didin Muhidin selaku ketua MT'TG regional II Jabodetabek, Hari Sandi Atmaja selaku ketua MTTG pusat, beberapa pengurus harian yang menghandel kajian Zuhur di masjid Al-Istiqomah Telkom Landmark Tower, dan beberapa karyawan Telkom yang mengikuti kajian Zuhur di masjid Al-Istiqomah Telkom Landmark Tower.

${ }^{23}$ Nanang Martono, Metode Penelitian Kuantitatif Analisis Isi dan Data Sekunder, hal. 159

${ }^{24}$ Nana Sudjana, Pengantar Statistik, Jakarta: Bumi Aksara, 1993, hal. 40

${ }^{25} \mathrm{Ibid}$, hal. 176 
Pada penelitian ini terdapat delapan puluh jamaah yang dijadikan responden yakni jamaah laki-laki dan perempuan yang mengikuti kajian Zuhur. Jika dilihat dari karakteristik jamaah yang hadir pada kajian Zuhur yang diselenggarakan oleh Masjid Al-Istiqomah Telkom Landmark Tower, mempunyai beberapa perbedaan baik dari segi jenis kelamin, maupun kehadiran dalam mengikuti kajian dalam satu pekan yang diselenggarakan selama 4 hari mulai dari hari Senin hingga Kamis. Untuk lebih jelas dapat dilihat pada grafik berikut:

\section{Grafik 1 \\ Responden Berdasarkan Jenis Kelamin}

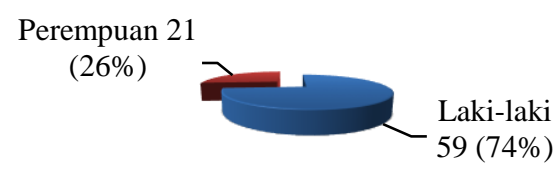

Dari grafik di atas, dapat diketahui bahwa responden dengan jenis kelamin laki-laki lebih dominan atau lebih banyak yaitu sebanyak 59 orang atau $74 \%$ dibanding yang berjenis kelamin perempuan yaitu sebanyak 21 orang atau 26\%. Berdasarkan tabel tersebut dapat dilihat bahwa mayoritas responden yang mengisi angket adalah laki-laki, karena sebagian besar jamaah yang hadir untuk mengikuti kajian Zuhur adalah laki-laki. Oleh karenanya, jamaah laki-laki atau responden yang berjenis kelamin laki-laki lebih banyak dibanding dengan jamaah yang berjenis kelamin perempuan.

\section{Grafik 2}

Responden berdasarkan jumlah kehadiran dalam satu pekan

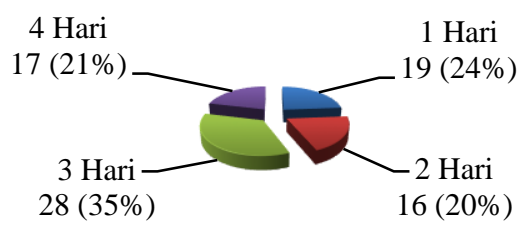

Kajian Zuhur yang dilaksanakan di Masjid Al-Istiqomah diadakan selama 4 hari dalam satu pekan. Dimulai dari hari Senin hingga hari Kamis. Dari grafik di atas, dapat diketahui bahwa 80 responden yang mengisi angket tidak semuanya mengikuti kajian Zuhur selama 4 hari dalam satu pekan. Dari 80 responden 19 orang atau 24\% jamaah mengikuti kajian sebanyak 1 hari saja dalam satu pekan. 16 orang atau 20\% jamaah mengikuti kajian 2 hari dalam satu pekan. 28 orang atau 35\% jamaah 
mengikuti kajian 3 hari dalam satu pekan dan 17 orang atau 21\% jamaah mengikuti kajian selama 4 hari dalam satu pekan. Hal ini menunjukkan bahwa sebagian besar responden mengikuti kajian Zuhur selama 3 hari dalam satu pekan.

Pada penelitian ini terdapat delapan puluh jamaah yang dijadikan responden yakni jamaah laki-laki dan perempuan yang mengikuti kajian Zuhur. Data diperoleh dengan penyebaran angket tertutup kepada 80 responden dengan jumlah soal 29 item yang mencakup 9 soal untuk variabel $\mathrm{X}$ dan 20 soal untuk variabel $\mathrm{Y}$, untuk memudahkan dalam menganalisa dan menginterpretasikan tiap-tiap item maka berikut ini akan dikemukakan dalam bentuk grafik. Tiap grafik berisi satu item pernyataan. Deskripsi selanjutnya dapat dilihat dari grafik berikut:

\section{Grafik 3}

Penceramah menyampaikan kajian dengan bahasa yang santun dan mudah dipahami

Kadang-kadang $3(3,75 \%)$

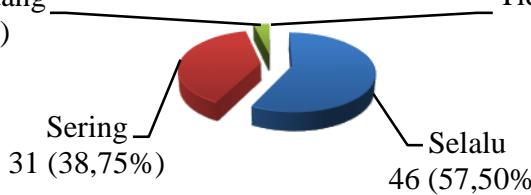
Tidak Pernah $0 \%$

Dari grafik di atas menunjukkan bahwa 57,50\% responden menyatakan bahwa penceramah dalam kajian Zuhur selalu menyampaikan kajian dengan bahasa yang santun dan mudah dipahami, 38,75\% menyatakan sering, dan 3,75\% menjawab kadang-kadang. Hal ini menunjukkan bahwa sebagian besar responden menyatakan bahwa penceramah dalam kajian Zuhur selalu menyampaikan kajian dengan bahasa yang santun dan mudah dipahami.

\section{Grafik 4}

Intonasi bicara penceramah mudah untuk didengar

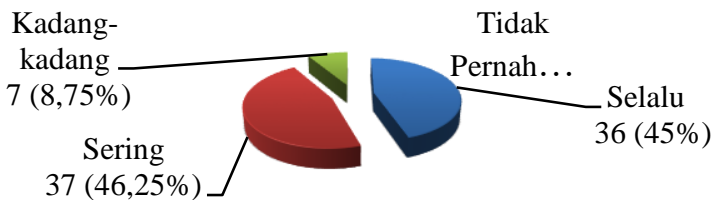

Dari grafik di atas menunjukkan bahwa 45\% responden menyatakan bahwa intonasi bicara penceramah selalu mudah untuk didengar, 46,25\% menyatakan sering, dan 8,75\% menjawab kadangkadang. Hal ini menunjukkan bahwa sebagian besar responden menyatakan intonasi bicara penceramah dalam kajian Zuhur sering mudah untuk didengar.

\section{Grafik 5}


Gaya bicara penceramah saat berceramah tidak menjemukan

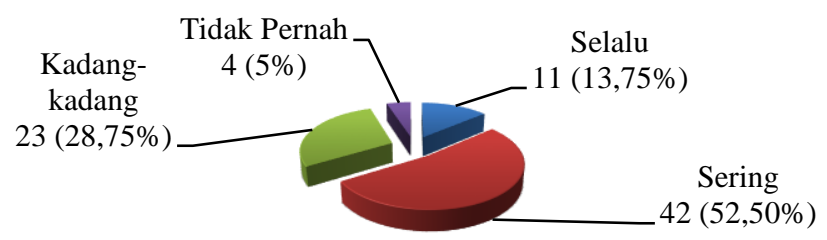

Dari grafik di atas menunjukkan bahwa $13,75 \%$ responden menyatakan bahwa gaya bicara penceramah saat berceramah selalu tidak menjemukan, $52,50 \%$ menyatakan sering, $28,75 \%$ menjawab kadangkadang, dan 5\% menjawab tidak pernah. Hal ini menunjukkan bahwa sebagian besar responden menyatakan gaya bicara penceramah saat berceramah sering tidak menjemukan.

\section{Grafik 6}

Materi yang disampaikan oleh penceramah sesuai dengan kebutuhan karyawan

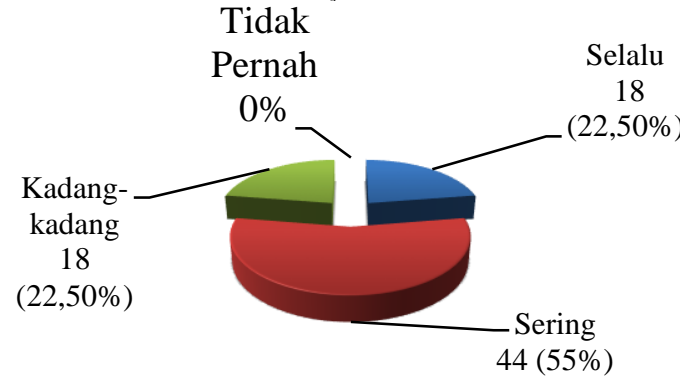

Dari grafik di atas menunjukkan bahwa $22,50 \%$ responden menyatakan bahwa materi yang disampaikan oleh penceramah selalu sesuai dengan kebutuhan karyawan, 55\% menyatakan sering, dan 22,50\% menjawab kadang-kadang. Hal ini menunjukkan bahwa sebagian besar responden menyatakan bahwa materi yang disampaikan oleh penceramah sering sesuai dengan kebutuhan karyawan.

\section{Grafik 7}

Tema kajian yang disampaikan bervariasi, sehingga jamaah tidak bosan

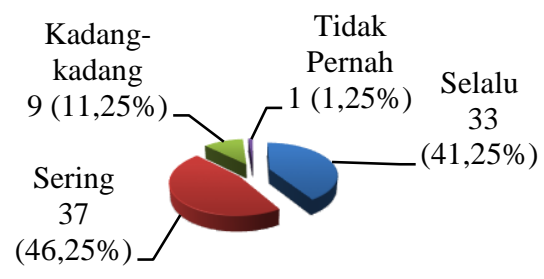


Dari grafik di atas menunjukkan bahwa $41,25 \%$ responden menyatakan bahwa tema kajian yang disampaikan selalu bervariasi, sehingga jamaah tidak bosan, 46,25\% menyatakan sering, $11,25 \%$ menyatakan kadang-kadang, dan 1,25\% menjawab tidak pernah. Hal ini menunjukkan bahwa sebagian besar responden menyatakan bahwa tema kajian yang disampaikan sering bervariasi, sehingga jamaah tidak bosan.

\section{Grafik 8}

Penceramah menggunakan metode kisah dalam penyampaian kajian

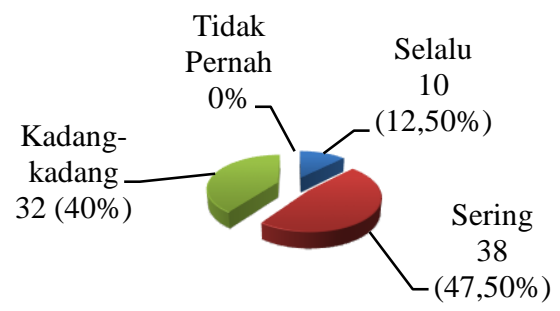

Dari grafik di atas menunjukkan bahwa $12,50 \%$ responden menyatakan bahwa penceramah selalu menggunakan metode kisah dalam penyampaian kajian, 47,50\% menyatakan sering, dan 40\% menjawab kadang-kadang. Hal ini menunjukkan bahwa sebagian besar responden menyatakan penceramah sering menggunakan metode kisah dalam penyampaian kajian.

\section{Grafik 9}

Penceramah membuka sesi tanya jawab saat kajian

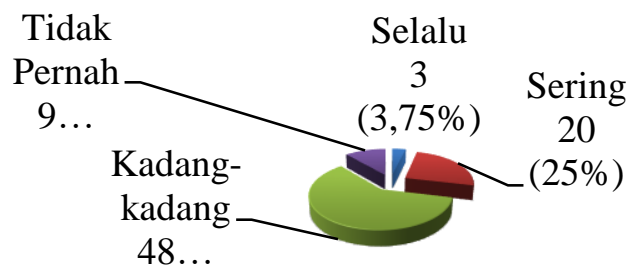

Dari grafik di atas menunjukkan bahwa 3,75\% responden menyatakan bahwa penceramah selalu membuka sesi tanya jawab saat kajian, 25\% menyatakan sering, 60\% menyatakan kadang-kadang, dan $11,25 \%$ menjawab tidak pernah. Hal ini menunjukkan bahwa sebagian besar responden menyatakan penceramah kadang-kadang membuka sesi tanya jawab saat kajian.

\section{Grafik 10}

Penceramah menggunakan nasehat yang membekas di hati 


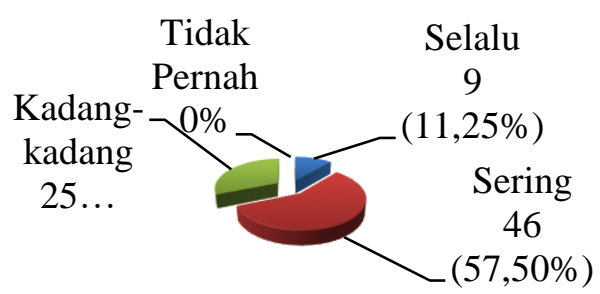

Dari grafik di atas menunjukkan bahwa $11,25 \%$ responden menyatakan bahwa penceramah selalu menggunakan nasehat yang membekas di hati, 57,50\% menyatakan sering, dan 31,25\% menjawab kadang-kadang. Hal ini menunjukkan bahwa sebagian besar responden menyatakan penceramah sering menggunakan nasehat yang membekas di hati.

\section{Grafik 11}

Panitia membuat pamplet online (flayer) yang dipublikasikan ke jamaah sebelum kajian dimulai

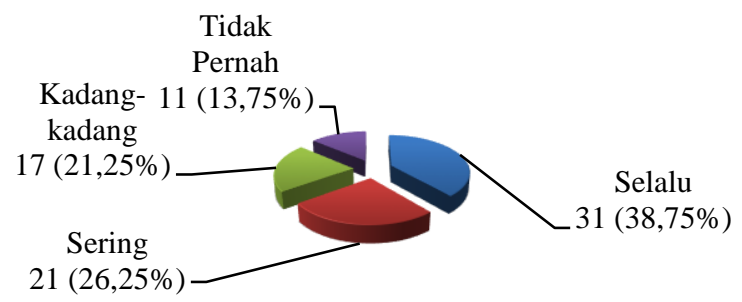

Dari grafik di atas menunjukkan bahwa 38,75\% responden menyatakan bahwa panitia selalu membuat pamplet online (flayer) yang dipublikasikan ke jamaah sebelum kajian dimulai, 26,25\% menyatakan sering, 21,25\% menyatakan kadang-kadang, dan 13,75\% menjawab tidak pernah. Hal ini menunjukkan bahwa sebagian besar responden menyatakan bahwa panitia selalu membuat pamplet online (flayer) yang dipublikasikan ke jamaah sebelum kajian dimulai.

\section{Grafik 12}

Melaksanakan sholat fardhu diawal waktu secara berjamaah

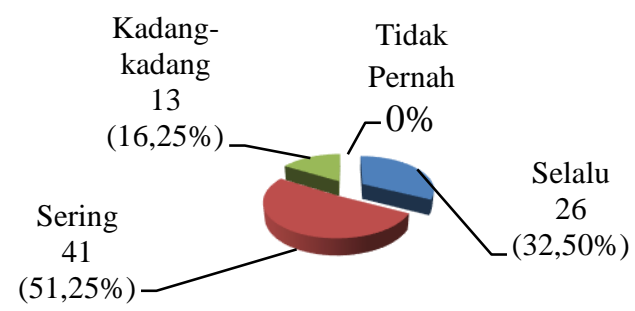

Dari grafik di atas menunjukkan bahwa 32,50\% responden menyatakan bahwa responden menyatakan selalu melaksanakan sholat fardhu diawal waktu secara berjamaah, 51,25\% menyatakan sering, dan 
16,25\% menjawab kadang-kadang. Hal ini menunjukkan bahwa sebagian besar responden menyatakan sering melaksanakan sholat fardhu diawal waktu secara berjamaah.

\section{Grafik 13}

Apabila ada kotak infaq, saya menyisihkan sebagian uang untuk diinfaqkan

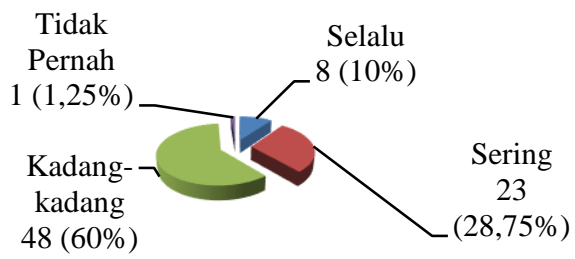

Dari grafik di atas menunjukkan bahwa $10 \%$ responden menyatakan bahwa apabila ada kotak infaq, selalu menyisihkan sebagian uang untuk diinfaqkan, 28,75\% menyatakan sering, 60\% menyatakan kadang-kadang, dan 1,25\% menjawab tidak pernah. Hal ini menunjukkan bahwa sebagian besar responden menyatakan apabila ada kotak infaq, kadang-kadang menyisihkan sebagian uang untuk diinfaqkan.

\section{Grafik 14}

Membaca basmalah (doa) ketika akan memulai pekerjaan

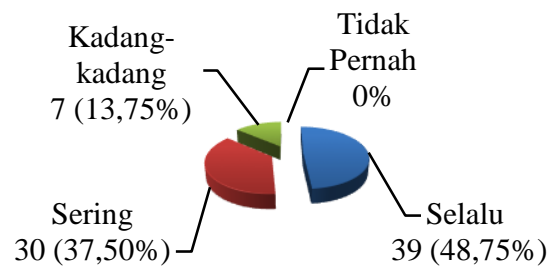

Dari grafik di atas menunjukkan bahwa $48,75 \%$ responden menyatakan bahwa selalu membaca basmalah (doa) ketika akan memulai pekerjaan, $37,50 \%$ menyatakan sering, $13,75 \%$ menyatakan kadangkadang. Hal ini menunjukkan bahwa sebagian besar responden menyatakan selalu membaca basmalah (doa) ketika akan memulai pekerjaan.

\section{Grafik 15}

Meminta petunjuk Allah Subhaanahu wa Ta'ala dalam setiap mengambil keputusan 


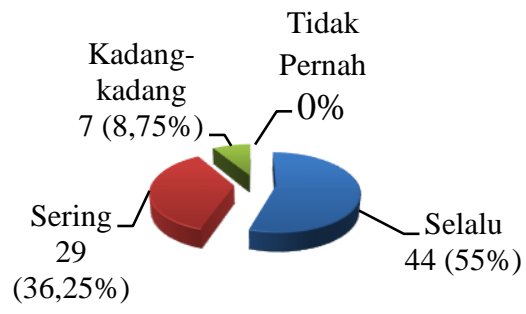

Dari grafik di atas menunjukkan bahwa 55\% responden menyatakan bahwa selalu meminta petunjuk Allah Subhaanahu wa Ta'ala dalam setiap mengambil keputusan, 36,25\% menyatakan sering, 8,75\% menyatakan kadang-kadang. Hal ini menunjukkan bahwa sebagian besar responden menyatakan selalu meminta petunjuk Allah Subbaanabu wa Ta'ala dalam setiap mengambil keputusan.

\section{Grafik 16}

Merasa gelisah dan menyesal ketika melakukan kesalahan

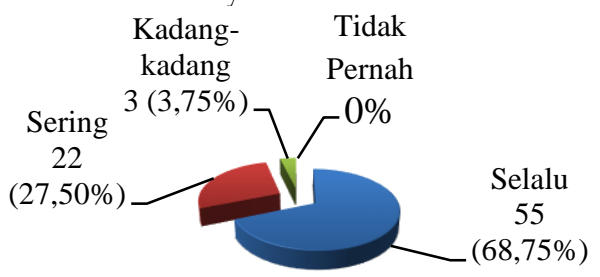

Dari grafik di atas menunjukkan bahwa $68,75 \%$ responden menyatakan bahwa menyatakan selalu merasa gelisah dan menyesal ketika melakukan kesalahan, 27,50\% menyatakan sering, dan 3,75\% menjawab kadang-kadang. Hal ini menunjukkan bahwa sebagian besar responden menyatakan selalu merasa gelisah dan menyesal ketika melakukan kesalahan.

\section{Grafik 17}

Bersemangat dalam bekerja untuk mendapat ridho Allah Subbaanahu wa Ta'ala

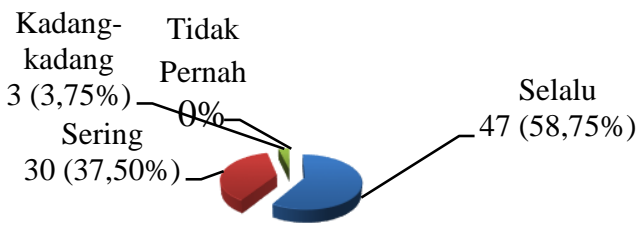

Dari grafik di atas menunjukkan bahwa 58,75\% responden menyatakan bahwa selalu bersemangat dalam bekerja untuk mendapat ridho Allah Subbaanabu wa Ta'ala, 37,50\% menyatakan sering, dan 3,75\% menjawab kadang-kadang. Hal ini menunjukkan bahwa sebagian besar 
responden menyatakan selalu bersemangat dalam bekerja untuk mendapat ridho Allah Subhaanabu wa Ta'ala.

\section{Grafik 18}

Bersyukur dan mengucap hamdalah (alhamdulillah) ketika mendapat nikmat

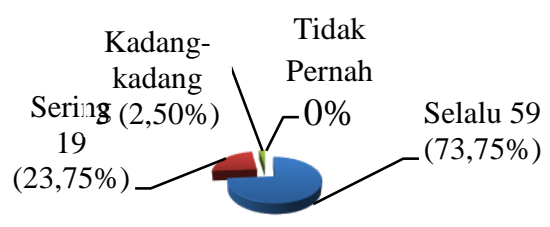

Dari grafik di atas menunjukkan bahwa 73,75\% responden menyatakan bahwa selalu bersyukur dan mengucap hamdalah (alhamdulillah) ketika mendapat nikmat, 23,75\% menyatakan sering, dan $2,50 \%$ menjawab kadang-kadang. Hal ini menunjukkan bahwa sebagian besar responden menyatakan selalu bersyukur dan mengucap hamdalah (albamdulillab) ketika mendapat nikmat.

\section{Grafik 19}

Apabila mendapat ujian, bersabar dan yakin bahwa ujian tersebut baik untuk Anda

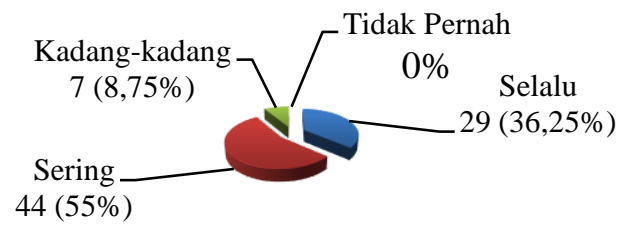

Dari grafik di atas menunjukkan bahwa 36,25\% responden menyatakan bahwa apabila mendapat ujian, selalu bersabar dan yakin bahwa ujian tersebut baik untuk dirinya, 55\% menyatakan sering, dan $8,75 \%$ menjawab kadang-kadang. Hal ini menunjukkan bahwa sebagian besar responden menyatakan sering apabila mendapat ujian, bersabar dan yakin bahwa ujian tersebut baik untuk dirinya.

Grafik 20

Mengucapkan salam ketika bertemu dengan rekan kerja 


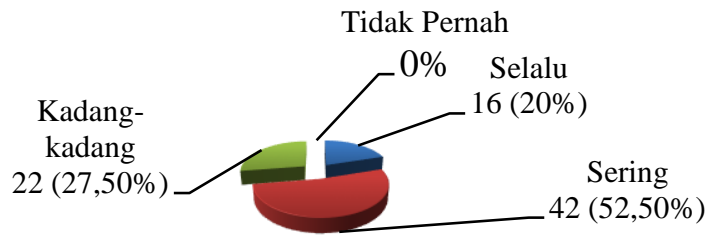

Dari grafik di atas menunjukkan bahwa 20\% responden menyatakan bahwa selalu mengucapkan salam ketika bertemu dengan rekan kerja, 52,50\% menyatakan sering, dan 27,50\% menjawab kadangkadang. Hal ini menunjukkan bahwa sebagian besar responden menyatakan sering mengucapkan salam ketika bertemu dengan rekan kerja.

\section{Grafik 21}

Mendoakan dan menjenguk saudara yang sakit

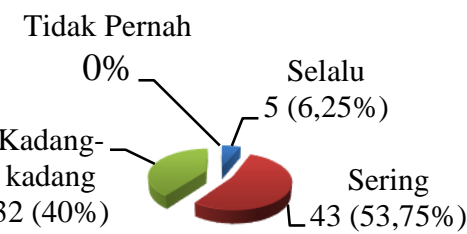

Dari grafik di atas menunjukkan bahwa 6,25\% responden menyatakan bahwa selalu mendoakan dan menjenguk saudara yang sakit, 53,75\% menyatakan sering, dan 40\% menjawab kadang-kadang. Hal ini menunjukkan bahwa sebagian besar responden menyatakan sering mendoakan dan menjenguk saudara yang sakit.

Grafik 22

Membantu rekan kerja yang sedang mengalami kesulitan

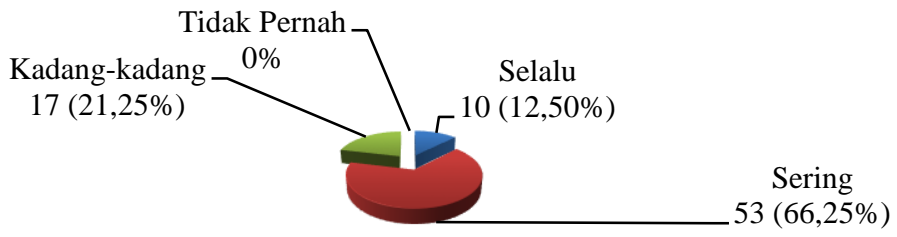

Dari grafik di atas menunjukkan bahwa $12,50 \%$ responden menyatakan bahwa selalu membantu rekan kerja yang sedang mengalami kesulitan, 66,25\% menyatakan sering, dan 21,25\% menjawab kadangkadang. Hal ini menunjukkan bahwa sebagian besar responden 
menyatakan sering membantu rekan kerja yang sedang mengalami kesulitan.

\section{Grafik 23}

Senang jika rekan kerja berprestasi dan mendapat penghargaan dari atasan

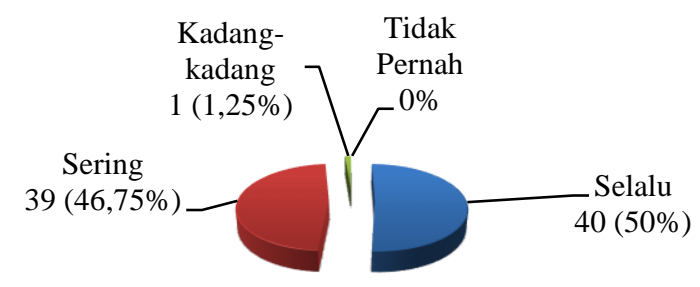

Dari grafik di atas menunjukkan bahwa 50\% responden menyatakan bahwa selalu senang jika rekan kerja berprestasi dan mendapat penghargaan dari atasan, 46,75\% menyatakan sering, dan 1,25\% menyatakan kadang-kadang. Hal ini menunjukkan bahwa sebagian besar responden menyatakan selalu senang jika rekan kerja berprestasi dan mendapat penghargaan dari atasan.

\section{Grafik 24}

Menjalankan perintah dari pimpinan dengan senang hati

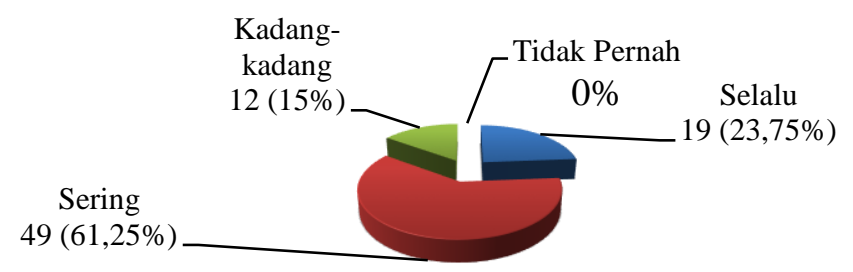

Dari grafik di atas menunjukkan bahwa $23,75 \%$ responden menyatakan bahwa selalu menjalankan perintah dari pimpinan dengan senang hati, $61,25 \%$ menyatakan sering, dan 15\% menjawab kadangkadang. Hal ini menunjukkan bahwa sebagian besar responden menyatakan bahwa sering menjalankan perintah dari pimpinan dengan senang hati.

\section{Grafik 25}

Datang ke kantor tepat waktu 


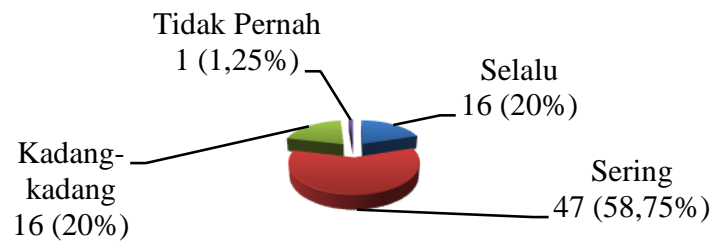

Dari grafik di atas menunjukkan bahwa 20\% responden menyatakan bahwa selalu datang ke kantor tepat waktu, 58,75\% menyatakan sering, 20\% menyatakan kadang-kadang, dan $1,25 \%$ menjawab tidak pernah. Hal ini menunjukkan bahwa sebagian besar responden sering datang ke kantor tepat waktu.

Grafik 26

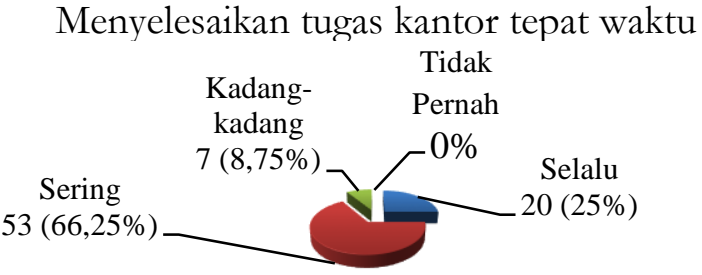

Dari grafik di atas menunjukkan bahwa 25\% responden menyatakan bahwa selalu menyelesaikan tugas kantor tepat waktu, $66,25 \%$ menyatakan sering, dan 8,75\% menyatakan kadang-kadang. Hal ini menunjukkan bahwa sebagian besar responden menyatakan sering menyelesaikan tugas kantor tepat waktu.

\section{Grafik 27}

Menjaga lisan dari pembicaraan yang tidak bermanfaat seperti membicarakan aib rekan kerja (gosip)

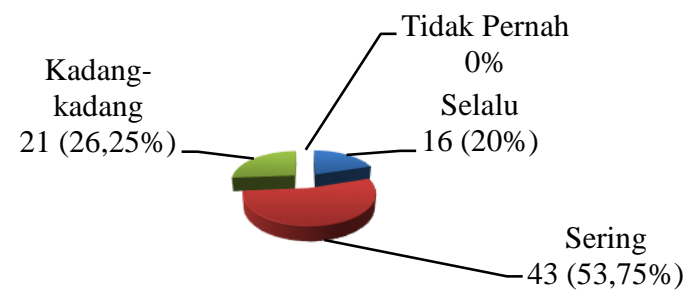

Dari grafik di atas menunjukkan bahwa 20\% responden menyatakan bahwa selalu menjaga lisan dari pembicaraan yang tidak bermanfaat seperti membicarakan aib rekan kerja (gosip), 53,75\% menyatakan sering, dan 26,25\% menyatakan kadang-kadang. Hal ini menunjukkan bahwa sebagian besar responden menyatakan sering menjaga 
lisan dari pembicaraan yang tidak bermanfaat seperti membicarakan aib rekan kerja (gosip).

\section{Grafik 28}

Melakukan introspeksi diri atas kesalahan yang telah dilakukan Kadang-

kadang

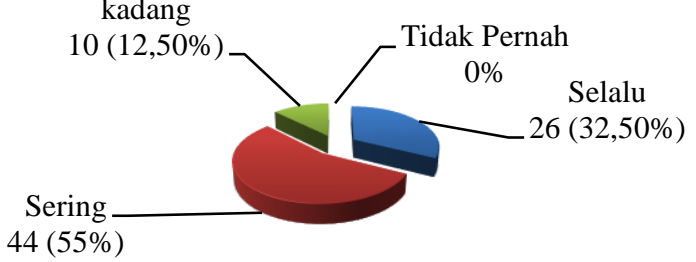

Dari grafik di atas menunjukkan bahwa 32,50\% responden menyatakan bahwa selalu melakukan introspeksi diri atas kesalahan yang telah dilakukan, 55\% menyatakan sering, dan 12,50\% menyatakan kadangkadang. Hal ini menunjukkan bahwa sebagian besar responden menyatakan bahwa sering melakukan introspeksi diri atas kesalahan yang telah dilakukan.

\section{Grafik 29}

Mengucap istighfar ketika melakukan kesalahan

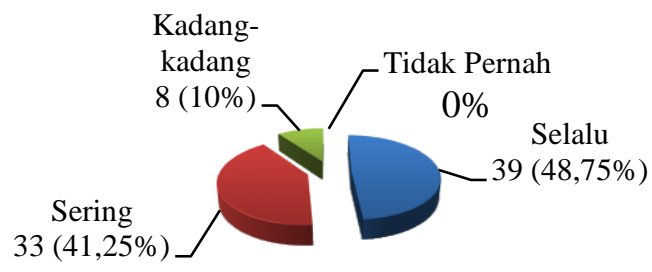

Dari grafik di atas menunjukkan bahwa $48,75 \%$ responden menyatakan bahwa selalu mengucap istighfar ketika melakukan kesalahan, 41,25\% menyatakan sering, dan 10\% menjawab kadang-kadang. Hal ini menunjukkan bahwa sebagian besar responden menyatakan selalu mengucap istighfar ketika melakukan kesalahan.

\section{Grafik 30}

Yakin bahwa semua nikmat itu adalah pemberian dari Allah Subhaanahu wa Ta'ala sehingga tidak membuat sombong atas apa yang dimiliki 


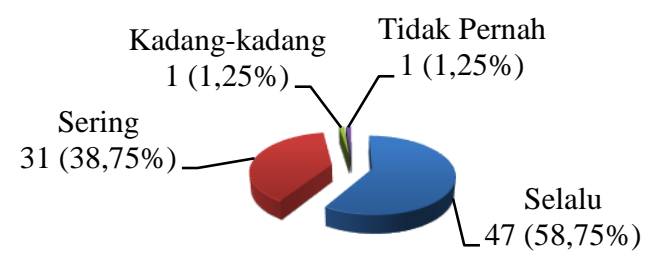

Dari grafik di atas menunjukkan bahwa 58,75\% responden menyatakan bahwa selalu yakin bahwa semua nikmat itu adalah pemberian dari Allah Subbaanabu wa Ta'ala sehingga tidak membuat sombong atas apa yang dimiliki, 38,75\% menyatakan sering, 1,25\% menyatakan kadangkadang, dan 1,25\% menjawab tidak pernah. Hal ini menunjukkan bahwa sebagian besar responden menyatakan bahwa selalu yakin bahwa semua nikmat itu adalah pemberian dari Allah Subhaanabu wa Ta'ala sehingga tidak membuat sombong atas apa yang dimiliki.

Grafik 31

Apabila ada masalah, menyelesaikan dengan baik-baik tanpa emosi

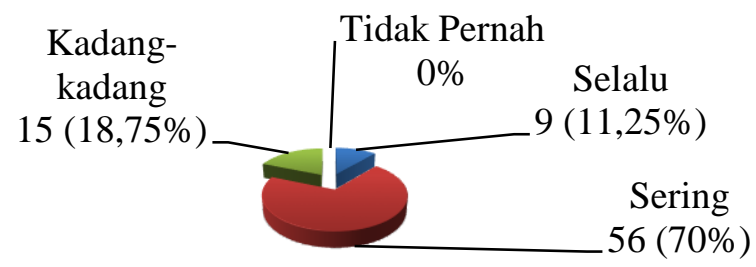

Dari grafik di atas menunjukkan bahwa $11,25 \%$ responden menyatakan bahwa apabila ada masalah selalu menyelesaikan dengan baikbaik tanpa emosi, 70\% menyatakan sering, dan 18,75\% menjawab kadangkadang. Hal ini menunjukkan bahwa sebagian besar responden menyatakan bahwa apabila ada masalah, sering menyelesaikan dengan baikbaik tanpa emosi.

\section{Analisis Dengan Korelasi Product Moment}

Uji korelasi product moment dengan SPSS digunakan untuk mengetahui ada atau tidaknya hubungan antara dua variabel. 
Tabel 6

Korelasi Product Moment

\begin{tabular}{|c|c|c|c|}
\hline \multicolumn{4}{|c|}{ Correlations } \\
\hline & & $\mathrm{X}$ & $\mathrm{Y}$ \\
\hline \multirow[t]{3}{*}{$\mathrm{X}$} & $\begin{array}{l}\text { Pearson } \\
\text { Correlation }\end{array}$ & 1 &, $285^{*}$ \\
\hline & Sig. (2-tailed) & & ,010 \\
\hline & $\mathrm{N}$ & 80 & 80 \\
\hline \multirow[t]{3}{*}{$\mathrm{Y}$} & $\begin{array}{l}\text { Pearson } \\
\text { Correlation }\end{array}$ & ,285* & 1 \\
\hline & Sig. (2-tailed) & ,010 & \\
\hline & $\mathrm{N}$ & 80 & 80 \\
\hline
\end{tabular}

Dari perhitungan yang didapat melalui SPSS dapat diketahui bahwa nilai koefisien atau $r_{x y}$ adalah sebesar 0,285. Pada tabel signifikansi $5 \%$ diperoleh data 0,220 , sehingga nilai $\mathrm{r}_{\mathrm{xy}}$ lebih besar dari $\mathrm{r}$ tabel. Sehingga terdapat korelasi positif antara kajian Zuhur dengan pembentukan akhlak karyawan muslim Telkom di masjid Al-Istiqomah Telkom Landmark Tower.

Oleh karena itu, dapat dikatakan bahwa hipotesa nol $\left(\mathrm{H}_{0}\right)$ yang mengatakan, "tidak terdapat pengaruh antara kajian Zuhur terhadap pembentukan akhlak karyawan di masjid Al-Istiqomah Telkom Landmark Tower" ditolak karena teruji kebenarannya, yaitu $r$ tabel pada tahap signifikan 5\% lebih kecil dari $\mathrm{r}_{\mathrm{xy}}$. Sedangkan hipotesa kerja alternative $\left(\mathrm{H}_{\alpha}\right)$ yang mengatakan, "Terdapat pengaruh yang signifikan antara kajian Zuhur dengan pembentukan akhlak karyawan Telkom di masjid Al-Istiqomah Telkom Landmark Tower" diterima, karena teruji kebenarannya, yaitu nilai hasil perhitungannya lebih besar dari nilai $r$ tabel.

Untuk mengetahui seberapa besar pengaruh kajian Zuhur (variabel $\mathrm{X}$ ) terhadap pembentukan akhlak karyawan (variabel $\mathrm{Y}$ ) digunakan rumus sebagai berikut:

$$
\begin{aligned}
\mathrm{KD} & =\mathrm{r}^{2} \times 100 \% \\
& =0,285 \times 100 \% \\
& =0,285^{2} \times 100 \% \\
& =0,081225 \times 100 \% \\
& =8,1225 \%
\end{aligned}
$$




$$
=8,1 \%
$$

Dari perhitungan di atas, diperoleh koefisien determinan sebesar 8,1\%, hal ini menunjukkan bahwasanya variabel $\mathrm{X}$ (kajian Zuhur) telah memberikan pengaruh terhadap variabel Y (akhlak karyawan) sebesar $8,1 \%$.

Salah satu misi dakwah Rasulullah Shallallabu 'Alaibi wa Sallam adalah menyempurnakan akhlak manusia. Akhlak mulia adalah perkara yang sangat penting. Bahkan berdakwah menuju kemuliaan akhlak merupakan salah satu tujuan terpenting diutusnya Rasulullah Shallallahu 'Alaibi wa Sallam. Sebagaimana sabda beliau:

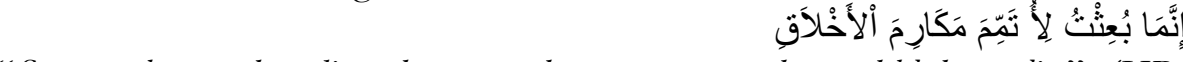
"Sesunggubnya aku diutuskan untuk menyempurnakan akblak mulia." (HR. Ahmad dalam Musnadnya (no. 8952), Al-Bukhari dalam al-Adab al-Mufrad (no. 273), al-Baihaqi dalam Syu'ab al-Iman (no. 7609), al-Khara'ith dalam Makarim al-Akhlaq (no. 1) dan lainnya).

Kajian Zuhur merupakan salah satu sarana dakwah yang digunakan oleh perusahaan Telkom untuk melakukan pembinaan spiritual bagi para karyawannya. Dakwah melalui kajian Zuhur ini dimulai dari menginternalisasi makna spiritual kerja, kepada para pekerja disampaikan bahwa bekerja tidak hanya sekedar untuk memenuhi kebutuhan fisik, namun juga sebagai ibadah pada Allah Subhaanabu wa Ta'ala. Setelah makna spiritual terinternalisasi, motivasi kerja pun dibangun kembali agar bekerja tidak hanya untuk kebutuhan fisik. Integritas bekerja kemudian dibangun untuk mengamalkan kejujuran dalam bekerja. Setelah itu kekuatan spiritual kerja dibangun sehingga para pekerja diharapkan dapat bekerja dengan cinta karena mensyukuri apa yang diberikan oleh Allah Subbanabu wa Ta'ala.

Dalam penelitian ini digunakan dua variabel yaitu Kajian Zuhur (X) dan akhlak karyawan (Y) untuk mengetahui pengaruh kajian Zuhur terhadap pembentukan akhlak karyawan muslim Telkom di masjid AlIstiqomah Telkom Landmark Tower. Berdasarkan hasil penelitian ini dapat diketahui bahwa kajian Zuhur berpengaruh positif terhadap pembentukan akhlak karyawan muslim Telkom di Masjid Al-Istiqomah Telkom Landmark Tower. Hal tersebut terlihat dari perubahan perilaku positif para karyawan pada kegiatan sehari-hari terutama di lingkungan kerja.

Sesuai dengan perhitungan yang didapat melalui SPSS dapat diketahui bahwa nilai koefisien atau $\mathrm{r}_{\mathrm{xy}}$ adalah sebesar 0,285. Pada tabel signifikansi $5 \%$ diperoleh data 0,220 , sehingga nilai $r_{x y}$ lebih besar dari $r$ 
tabel. Sehingga terdapat korelasi positif yang signifikan antara kajian Zuhur dengan pembentukan akhlak karyawan muslim Telkom. Berdasarkan korelasi product moment, bahwa kajian Zuhur (X) mempengaruhi akhlak karyawan (Y) hanya sebesar 0,285 . Hal tersebut menunjukkan korelasi antara variabel $\mathrm{X}$ dan $\mathrm{Y}$ termasuk dalam kategori lemah atau rendah.

Untuk mengetahui seberapa besar kontribusi kajian Zuhur dalam membentuk akhlak karyawan, dengan menggunakan koefisiensi determinasi yang hasilnya 8,1\%. Menunjukkan bahwa 8,1\% akhlak karyawan muslim yang mengikuti kajian Zuhur di Masjid Al-Istiqomah Telkom Landmark Tower dipengaruhi oleh kajian Zuhur dan sisanya dipengaruhi oleh variabel lain.

Ada beberapa faktor yang menyebabkan hasil korelasi antara kajian Zuhur dengan akhlak karyawan menghasilkan korelasi yang rendah. Faktor tersebut antara lain: Pertama, beberapa karyawan tidak mengikuti kajian Zuhur secara penuh selama 4 hari sesuai dengan yang telah dijadwalkan. Dari 80 responden 19 orang atau 24\% jamaah mengikuti kajian sebanyak 1 hari saja dalam satu pekan. 16 orang atau 20\% jamaah mengikuti kajian 2 hari. 28 orang atau 35\% jamaah mengikuti kajian 3 hari. 17 orang atau $21 \%$ jamaah mengikuti kajian selama 4 hari dalam satu pekan. Hal ini menunjukkan bahwa sebagian besar responden mengikuti kajian Zuhur selama 3 hari dalam satu pekan. Kedua, materi yang disampaikan belum bisa secara maksimal dipraktekkan dalam kehidupan sehari-hari para karyawan. Ketiga, ada variabel lain yang menyebabkan akhlak karyawan berubah dengan lebih baik, baik itu dari kajian yang diikutinya di luar kajian Zuhur ataupun beberapa faktor lain di luar dari yang telah disebutkan.

\section{KESIMPULAN}

Berdasarkan kajian bab-bab sebelumnya, maka dapat diambil kesimpulan sebagai berikut:

1. Adanya hubungan variabel $X$ dengan variabel $Y$. Dari perhitungan yang didapat melalui SPSS dapat diketahui bahwa nilai koefisien atau $r_{x y}$ adalah sebesar 0,285. Pada tabel signifikansi 5\% diperoleh data 0,220, sehingga nilai $r_{x y}$ lebih besar dari $r$ tabel. Sehingga terdapat korelasi positif antara kajian Zuhur dengan pembentukan akhlak karyawan muslim Telkom di Masjid Al-Istiqomah Telkom Landmark Tower. Berdasarkan Korelasi Product Moment, bahwa kajian Zuhur (X) mempengaruhi akhlak karyawan (Y) hanya 
sebesar 0,285. Hal tersebut menunjukkan bahwa korelasi antara variabel $\mathrm{X}$ dan $\mathrm{Y}$ termasuk kategori lemah atau rendah.

2. Kontribusi kajian Zuhur terhadap pembentukan akhlak karyawan Telkom, dengan menggunakan koefisien determinasi diperoleh hasil sebesar 8,1\%. Hal tersebut menunjukkan bahwa 8,1\% akhlak karyawan muslim Telkom di Masjid Al-Istiqomah Telkom Landmark Tower dipengaruhi oleh kajian Zuhur dan sisanya dipengaruhi oleh variabel yang lain.

\section{DAFTAR PUSTAKA}

Buku

Abdul Aziz bin Fathi as-Sayyid Nada.(2013). Ensiklopedi Adab Islami, Jakarta: Pustaka Imam Syafi'i.

Abidin, Yusuf Zainal (2013). Pengantar Retorika, Bandung: Pustaka Setia.

Ahmad Warsono Munawwir. (1996). Kamus Munawnir, Surabaya: Pustaka Progressif.

Al-Ammar. Hamdan bin Nashir bin Abdurrahman, Asalib al-Da'wah al-Mu'ashirah

Al-Anshariyyah, Ummu Annas Sumayyah bintu Muhammad. 2018. Meraib Kemuliaan Akblak, Jakarta: Griya Ilmu.

Ali Aziz, Moh., Ilmu Dakwah. (2009) Jakarta: Prenada Media Group.

Ammar, Abu dan Abu Fatiah Al-Adnani. (2009). Mizanul Muslim, Solo: Cordova Media.

As-Suhaimi, Fawaz bin Hulail. Pokok-pokok Dakwah Manhaj Salaf

Fawwaz bin Hulayyil as-Suhaimi. (2015). Begini Seharusnya Berdakwah. Jakarta:Darul Haq.

Hasanudin. (1996). Hukum Dakwah Tinjauan Aspek Hukum dalam Berdakwah di Indonesia, Jakarta: Pedoman Ilmu Jaya.

Ihsan, Ummu dan Abu Ihsan al-Atsari, Aktualisasi Akblak Muslim.

Martono, Nanang. (2011). Metode Penelitian Kuantitatif Analisis Isi dan Analisis Data Sekunder, Jakarta: Rajawali Pres.

Nazir, Mohammad . (2014). Metode Penelitian, Bogor: Ghalia Indonesia

Proyono. (2008). Metode Kuantitatif, Sidoarjo: Zifatama Publishing

Shidiq, A. Syamsuri.(1981). Da'wah dan Teknik Berkhutbah, Bandung: Pustaka Al-Ma'arif

Sudjana, Nana. (1993). Pengantar Statistik, Jakarta: Bumi Aksara.

Sugiyono. (2011). Metode Penelitian Kuantitatif Kualitatif dan R\&D, Bandung: Alfabeta

Yaqub, Hamzah. (1983). Etika Islam, Bandung: Diponegoro. 
Yunus, Mahmud. (2004). Kamus Bahasa Arab-Indonesia, Jakarta:Yayasan Penyelenggara/Penafsiran Al-Qur'an.

Zaidan, Abdul Karim (2005). Ushulud Da'wah, Beirut: Al-Resalah.

\section{Website}

Suhail, Ahmad Kusyairi. (2019) Pentingnya muhasabah, Republika.co.id

\section{Wawancara}

Muhidin, Didin. (2019). Ketua MTTG Regional II JABOTABES, wawancara, Ruang Mgr HR dan CDC Telkom Jakarta Timur.

Saksono, Hanung. (2019). Pengurus masjid Al-Istiqomah (bidang dakwah dan kemakmuran masjid), wawancara, Ruang sekretariat MTTG Gatsu Jakarta Selatan. 